\title{
ERROR ELIMINATION FOR CURRENT CONTROL LOOP FOR MULTI-FUNCTIONAL SINGLE-PHASE GRID-CONNECTED INVERTER
}

Purpose. Elimination of the error of the inverter current control loop by improving its structure and justifying the parameters, which will ensure compliance with the current quality standard at the common coupling to the distribution grid of the load and the multi-functional grid inverter at the output of the renewable source of electrical energy. Methodology. Synthesis of structure of current control loop based on analysis of processes in electrical circuits and computer simulation. Results. Relationships for determining the input voltage of the inverter, reactor inductance and modulation frequency in accordance with the grid voltage, the maximum values of the inverter current and the amplitude of its ripple when combining the function of the active power filter. Dependencies of the amplitude of the pulsations of the output current of the inverter and the errors in the fundamental harmonic in accordance with the voltage at the input of the inverter, the modulation frequency and inductance of the output reactor are obtained. Originality. The structure of the inverter current control loop has been improved with a combination of proportional, integrating and differentiating links, and their parameters have been determined to ensure compensation of the disturbing action on input of the reference and compensation of the error of current from the disturbing action of the grid voltage regardless of its value. Practical value. The obtained solutions are the basis for the design of converters of electric power systems with renewable sources of electricity with improved energy efficiency. References 10, figures 7.

Key words: multi-functional single-phase grid-connected inverter, nonlinear load, PWM, current control loop, current error compensation, THD, simulation.

Мета. Усунення похибки контуру регулювання струму інвертора иляхом удосконалення його структури та обтрунтування параметрів, що сприятиме відповідності стандарту якості струму в точці підключення до розподільчої мережі навантаження $і$ багатофункціонального мережевого інвертора на виході поновлювального джерела електроенергї̈. Методика. Синтез структури контуру регулювання струму на базі аналізу процесів у електричних колах з використанням комп'ютерного моделювання. Результати. Одержані залежності амплітуди пульсацій вихідного струму інвертора і похибки за основною гармонікою від напруги на вході інвертора, частоти ШІМ i індуктивності реактора. Співвідночення для визначення значень вхідної напруги інвертора, індуктивності реактору та частоти ШІМ згідно напрузі мережсі, максимальних значень струму інвертора та амплітуди його пульсацій за суміщенням функції силового активного фільтра. Наукова новизна. Удосконалено структуру контуру регулювання струму зі сполученням пропорційної, інтегруючої та диференціючої ланок і визначені їх параметри для забезпечення компенсації збурюючої дії за завданням і компенсації похибки струму від збурюючої дії напруги мережі незалежно від ї значення. Практичне значення. Отримані рішення є основою для проектування перетворювачів для систем 3 поновлювальними джерелами електроенергї̈ з покращеною енергоефективністю. Бібл. 10, рис. 7.

Ключові слова: багатофункціональний мережевий інвертор, нелінійне навантаження, ШІМ, контур регулювання струму, компенсація похибки струму, коефіціснт гармонік, моделювання.

Цель. Устранение погрешности контура регулирования тока инвертора путем совериенствования его структуры и обоснования параметров, что позволит обеспечить соответствие стандарту качества тока в точке подключения к распределительной сети нагрузки и многофункционального сетевого инвертора на выходе возобновляемого источника электроэнергии. Методика. Синтез структуры контура регулирования тока на базе анализа процессов в электрических цепях с использованием компьютерного моделирования. Результаты. Получены зависимости амплитуды пульсаций выходного тока инвертора и ошибки по основной гармонике от напряжения на входе инвертора, частоты ШИМ и индуктивности реактора. Соотночения для определения значений входного напряжения инвертора, индуктивности реактора и частоты ШИМ в соответствии с напряжением сети, максимальными значениями тока инвертора и амплитуды его пульсаций при совмещении функции силового активного фильтра. Научная новизна. Усовериенствована структура контура регулирования тока инвертора с сочетанием пропорционального, интегрирующего и дифференцирующего звеньев и определены их параметры для обеспечения компенсации возмущающего действия по заданию и компенсации погрешности тока от возмущающего действия напряжения сети независимо от его значения. Практическое значение. Полученные решения являются основой для проектирования преобразователей для систем с возобновляемыми источниками электроэнергии и улучиенной энергоэффективностью. Библ. 10 , рис. 7.

Ключевые слова: многофункциональный сетевой инвертор, нелинейная нагрузка, ШИМ, контур регулирования тока, компенсация ошибки тока, коэффициент гармоник, моделирование.

Introduction. The use of a renewable energy source (RES) implies the presence of a fairly complex and expensive conversion unit with an output grid-connected autonomous voltage inverter (AVI). Under natural conditions, the use of equipment for a photovoltaic solar cell does not exceed $20 \%$ [1]. For local objects (small enterprise, cottage, mini-hotel, etc.) with power supply from the RES and the distribution grid (DG) of the alternating current, increasing the efficiency of the use of the conversion unit is achieved by the use of a multifunctional grid-connected AVI with a combined function of the power active filter (PAF) [1-9] thanks to its roundthe-clock use to maintain the maximum (close to 1) power factor at the point of connection to the DG.

Typical solutions in the current control circuit (CCC) of the multi-functional AVIs are the use of a proportional-integral $(\mathrm{PI})$ regulator $[1,3,4]$, the 
proportional-resonant regulator [1], the relay current regulator $[1,2]$, the regulator on the basis of the fuzzylogic [5]. Solutions using PWM are More widespread [1, 3, 5-9]. The development of the CCC with the use of PWM is quite diverse. So, in $[1,5]$ the deviation $\Delta i_{C}$ of the current $i_{C}$ of the AVI relative to the given value $i_{C}^{*}$ $\left(\Delta i_{C}=i_{C}{ }_{C}-i_{C}\right)$ is fed to the proportional-integral (PI) current regulator. Since its efficiency is insufficient, variants are given in [1], where to the output voltage of the current regulator they add the voltage proportional to the DG voltage $u_{1}$, or to the output of the current regulator through the corresponding elements they add voltages proportional to $i_{C}^{*}, i_{C}$ and $u_{1}$.

The data above is not sufficient for perception and evaluation. For example, oscillograms of currents and indicators of circuits are given, but it is not indicated for which value (nominal, maximum, minimum). Structures are mostly declared, techniques for calculating parameters are absent. For a nonlinear load, the current $i_{C}$ is nonsinusoidal, compensating for the distortion of the load current form $i_{L}$. For this, the DG current $i_{1}=i_{C}-i_{L}$ contains the first harmonic, and higher (modulation) harmonics are suppressed by the filter. The operation error $i_{C}^{*}$ leads to the appearance in the current $i_{l}$ of higher harmonics of low order and the deterioration of the harmonic composition of the current, especially for its relatively small values, as evidenced by the oscillograms given in $[3,4]$. This complicates the issue of ensuring the correspondence the current harmonic composition to standards [10].

Consequently, the question of the implementation of the CCC of multi-functional grid-connected AVI has not been studied sufficiently and requires additional research.

The goal of the work is to eliminate the error of the inverter current control circuit by improving its structure and justification of the parameters that contributes to compliance with the current quality standard at the point of connection to the distribution grid of the load and the multifunctional grid-connected inverter at the output of the renewable energy source.

Main research materials. Consider the bridge circuit of the grid-connected AVI (Fig. 1) with the output $L C$-filter $\left(C_{f}\right.$ with insignificant $\left.R_{f}\right)$ at the point of connection to the AC grid with the voltage $u_{1}=U_{1 m} \sin \omega t$ and load. The input AVI circuit contains a solar cell (SC) with a voltage converter (VC) that supports a given voltage value $U$ at the AVI input.

The operation of the AVI in parallel with the DG in the mode of the current source provides for the fulfillment of the condition $U=a U_{1 m}(a>1)[6,9]$. The rate of change of the AVI output current $d i_{C} / d t$ in this case must exceed the maximum value for the current setting $d i^{*} / d t$. In the case of the formation of a sinusoidal current, the maximum value $\left(d i_{C}{ }_{C} / d t\right)_{\max }=\omega I_{C m \max }(\omega=2 \pi f$ is the angular frequency, $f=50 \mathrm{~Hz}, I_{C m \max }$ is the amplitude for the maximum value $I_{C \max }$ of the AVI current). The value of $d i_{C} / d t$ is determined by the voltage at the AVI output reactor

$$
u_{L}=u_{C}-u_{1}=L \frac{d i_{C}}{d t},
$$

where $u_{C}$ is the AVI voltage.
The least value of $u_{L}$ takes place at $u_{1}=U_{1 m}$ and $U_{L}=U-U_{1 m}=L \omega I_{C m \max }$. From here $a>1+L \omega I_{C m \max } / U_{1 m}$.

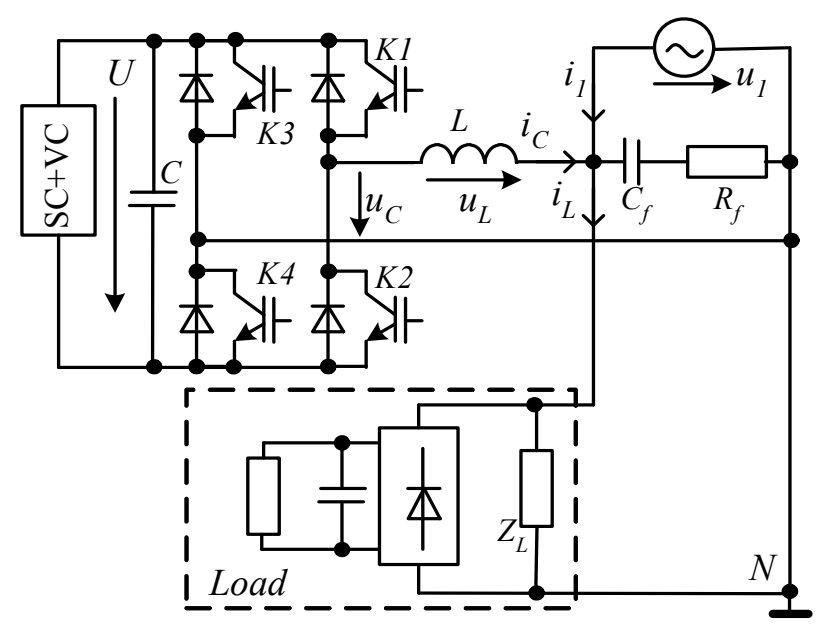

Fig. 1. The structure of the AVI power circles by connecting to grid and load

When combining the PAF function and operation on the nonlinear load, the AVI current shape is distorted, and the value of $a$ determines the possibility of working out the maximum value $\left(d i_{C}{ }_{C} / d t\right)_{\max }$ without error. At nonsinusoidal $i_{L}$, harmonics with multiplicity $i=1,3,5, \ldots$ and the amplitude $I_{m(i)}=I_{m(1)} / i$ are added. For the approximate estimation, let's take into account the largest of them the 3rd harmonic. We accept $I_{m(1)}=I_{C m \max }$, then

$$
a=1+\frac{L \omega I_{C m \max }}{U_{1 m}}+\frac{3 L \omega I_{C m \max }}{3 U_{1 m}}=1+2 \frac{L \omega I_{C m \max }}{U_{1 m}} .
$$

The inductance $L$ of the AVI reactor according to the relative value of $b$ of the voltage $U_{L}$ (by the 1st harmonic) for the maximum AVI current $I_{C \max } b=U_{L} / U_{1}=\omega L I_{C \max } / U_{1}$ (where $U_{1}$ is the current value of the DG voltage), we determine as

$$
L=\frac{b U_{1 m}}{\omega I_{C m \max }} .
$$

Accordingly, $a>1+2 b$.

The simplified structure of the CCC in accordance with (1) is shown in Fig. 2. The dotted line shows the compensation circuits. $T_{\mu}$ is the small uncompensated time constant of the AVI, which is determined by the frequency of PWM. The coefficients $k, j$, the compensating links of the DC and $\mathrm{K}$ are discussed further.

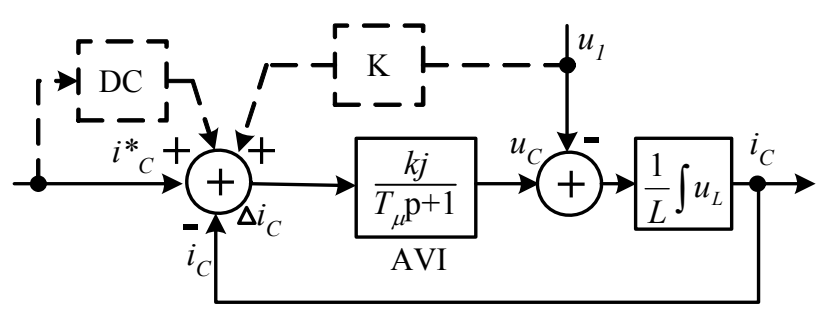

Fig. 2. Current control circuit of the AVI

According to Fig. 2, constantly acting disturbing influence, which causes the «static» error of current processing, is the voltage $u_{1}$, even at $i_{C}{ }_{C}=0$.

The typical nonlinear load of local objects is uncontrolled rectifiers (usually with an output capacitive 
filter) in the office equipment and household appliances that use the pulsed current $i_{V}$. For this, during the switching of the diodes in the AVI current setting, which is determined taking into account the load current, we have the corresponding to $i_{V}$ current change $i_{C}^{*}$ (by a jump-like change in the derivative of the current $i_{C}^{*}$ ). At a limited frequency of PWM, these current changes are delayed, which results in the appearance of a «dynamic» error and distortion of the current shape of the DG. So, we have a disturbance on the control signal. This leads to a deterioration of the harmonious composition of the grid current, making it difficult to ensure its compliance with the standards for values $I_{1 m} \leq 0.25 I_{C m \max }$.

Consider the implementation of PWM for the case when two reference voltages $u_{T R}$ and $\left(-u_{T R}\right)$ of a triangular shape with a modulation frequency $f_{M}$ which are symmetric with respect to 0 are used (Fig. 3). Switching of the keys of the first arm $(\mathrm{K} 1, \mathrm{~K} 2)$ is carried out provided that the given voltage $u^{*} \geq u_{T R}$, and of the second one $(\mathrm{K} 3, \mathrm{~K} 4)-u^{*} \leq-u_{T R}$.

In the absence of regulators in the PWM block, the voltage, which is proportional to $\Delta i_{C}$, is compared with $u_{T R}$. In the case of the formation of positive half-wave of $u_{C}$, two voltage values $U$ and 0 (for negative half-wave, respectively, $-U$ and 0 ) are used and the voltage $u_{L}$ takes the value:

- if $u_{C}=U$, then the value $u_{L}=U-u_{1}=L \frac{d i_{C}}{d t}$ and the current $i_{C}$ increases (the initial deviation $\Delta i_{C}$ relative to the average value of $\Delta i_{C A V}$ (error of current processing) is positive $\left(i_{C}^{*}>i_{C}\right)$ and decreases to zero and then becomes negative $\left.\left(i_{C}^{*}<i_{C}\right)\right)$ (Fig. 3);

- if $u_{C}=0$, then the value $u_{L}=0-u_{1}=L \frac{d i_{C}}{d t}$ and the current decreases $\left(\Delta i_{C}\right.$ increases to zero, and then becomes positive). Since $f_{M}$ is large enough, it can be assumed that on the modulation interval $T$ the voltage $u_{1}$ and current $i_{C}{ }_{C}$ are unchanged. Consequently, the current fluctuates relative to the given value and changes according to the linear law, the rate of its change depends on the values $u_{1}$ and $u_{C}$.

We assume that the current $i_{C}$ and, accordingly, $d i_{C} / d t$ vary according to the harmonic law. The amplitude of current pulsations $\Delta I_{C m}$ is determined by the coefficient of filling the pulses of the AVI voltage $\gamma=t_{o n} / T\left(t_{o n}\right.$ is the key activation time, $T$ is the modulation period) and does not depend on the current value. Therefore, we assume that the given value of the AVI current is zero. So, we have:

- at $u_{1} \rightarrow 0$, the value $\gamma \rightarrow 0$, accordingly, $\Delta I_{C m} \rightarrow 0$ (Fig. 3,a). For this, the mean value of the current deviation during the modulation period is $\Delta i_{C A V}(t)=0$. The rates of growth and decrease of current are different, which in the case of $\gamma>0$ leads to an increase $\left|\Delta i_{C A V}(t)\right|>0$. That is, the mean value $\left|\Delta i_{C A V}(t)\right|$ gradually increases;

- the value $\gamma=0.5$, when $\Delta I_{C m}$ is the maximum (Fig. 3,b), meets the condition

$$
\left.a U_{1 m}-U_{1 m} \sin \omega t=\mid-U_{1 m} \sin \omega t\right) \mid \text {, and }
$$

$$
\Delta I_{C m}=\Delta I_{C m \max }=\frac{a U_{1 m}}{16 L f_{M}} ;
$$

- at $u_{1}=U_{1 m}$, the value of $\gamma$ is maximal (Fig. 3,c), it can be found under the condition that $\int_{0}^{T} u_{L} d t=0$, or

$$
U_{1 m}(a-1) \gamma+U_{1 m}(0-1)(1-\gamma)=0 .
$$

Accordingly, $\gamma_{\max }=1 / a$ and

$$
\Delta I_{C m 1}=\frac{\gamma(a-1) U_{1 m}}{4 L f_{M}} .
$$

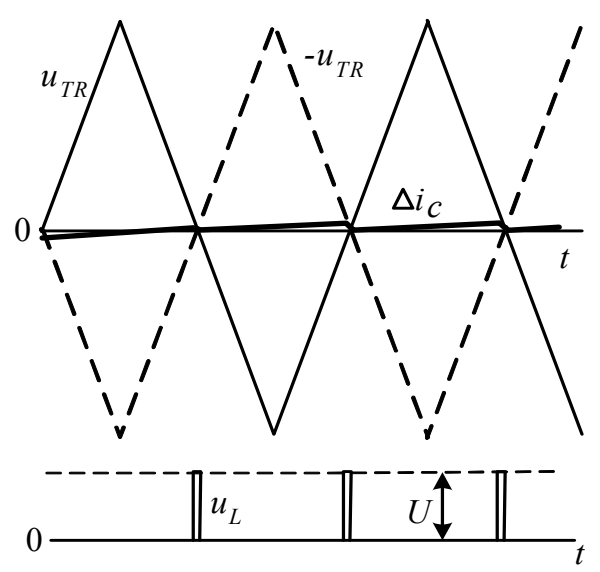

$a$
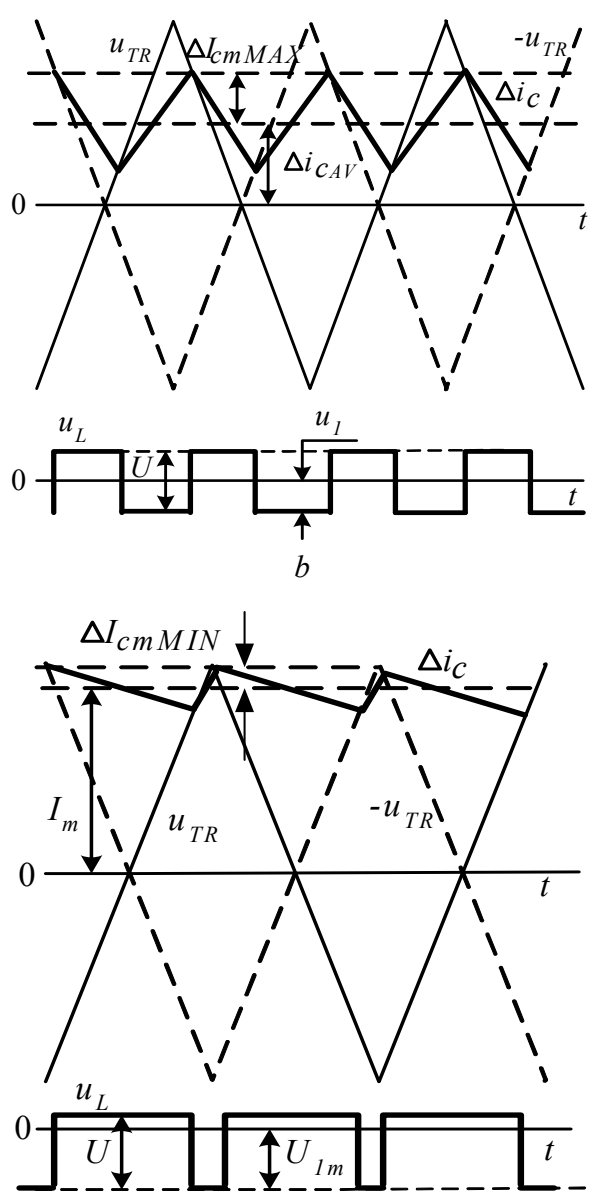

$c$

Fig. 3. Determination of amplitude of pulsations and error of current processing of the AVI with PWM 
We take into account the relation of the rate of change of $i_{C}$ and the reference voltage $\frac{d u_{T R}}{d t}>\frac{d i_{C}}{d t}$. The value $\frac{d u_{T R}}{d t}=4 u_{T R m} f_{M}$. The maximum value $d i_{C} / d t$ takes place, when $u_{L}=0-U_{1 m}=-U_{1 m}$ and equal to $\frac{d i_{C}}{d t}=\frac{U_{1 m}}{L}$. So, $\frac{d u_{T R}}{d t}=4 u_{T R m} f_{M} \geq \frac{U_{1 m}}{L} \quad\left(u_{T R m}\right.$ amplitude of $u_{T R}$ ), from here

$$
f_{M} \geq \frac{U_{1 m}}{4 u_{T R m} L} .
$$

Based on the condition $\int_{0}^{T} u_{L} d t=0$, we can determine dependencies $\gamma(t)$ and $\Delta I_{C m}(t)$. So, for $u_{C}>0$ we have $U_{1 m}(a-\sin \omega t) \gamma+U_{1 m}(0-\sin \omega t)(1-\gamma)=0$. From here

$$
\gamma=\frac{\sin \omega t}{a} .
$$

Current deviation amplitude $\Delta I_{C m}=\frac{\gamma(1-\gamma) a U_{1 m}}{2 L f_{M}}$. Taking into account the value of $\gamma$ we obtain $\Delta I_{C m}(t)=\frac{U_{1 m}}{2 a L f_{M}}(a \sin \omega t-0.5+0.5 \cos 2 \omega t)$. For $u_{C}<0$ we have the same situation. So,

$$
\begin{gathered}
\Delta I_{C m}(t)=\frac{U_{1 m}}{2 a L f_{M}}(|a \sin \omega t|-0.5+0.5 \cos 2 \omega t), \\
\Delta i_{C A V}(t)=\frac{u_{T R m}}{a} \sin \omega t .
\end{gathered}
$$

The boundary is the mode where the current error amplitude $I_{m}$ approaches $u_{T R m}$ and $\Delta I_{C m 1}=0$ at $a=1$. In general, it is necessary to fulfill the condition

$$
I_{m}+\Delta I_{C m 1} \leq u_{T R} \text {. }
$$

Otherwise there is an additional (superfluous) switching of the keys of the inverter.

The amplitude $u_{T R m}$ can be determined according to (5), then the amplitude of the fundamental harmonic of the current error, accordingly to (4) and (6) $I_{m} \leq \frac{U_{1 m}}{a 4 L f_{M}}$, or

$$
I_{m} \leq \frac{u_{T R m}}{a} .
$$

Values $\Delta I_{C m}$ at $\gamma=0.5$ and $\gamma_{\max }$ are, respectively, $\Delta I_{C m \text { max }} \leq \frac{a}{4} u_{T R m}, \Delta I_{C m 1}=\frac{(a-1)}{a} u_{T R m}$.

Let's turn to relative value $\Delta I_{C m \max }$ (to the amplitude $\left.I_{C \text { max }}\right) c=\frac{\Delta I_{C m \text { max }}}{I_{C_{m \text { max }}}}$, then accordingly to (2), (3)

$$
f_{M} \geq \frac{a \omega}{16 b c} \text {. }
$$

So, for example, at $b=0.15, c=0.05$, $a=1.3$ values $I_{m}=0.77 u_{T R m}, \Delta I_{C m \max }=0.325 u_{T R m}, \Delta I_{C m 1}=$ $=0.23 u_{T R m}$. If $I_{C \max }=25 \mathrm{~A}\left(I_{C m \max }=35.35 \mathrm{~A}\right)$, the modulation frequency by $(8) f_{M}=3400 \mathrm{~Hz}$, then $\Delta I_{C m \max }=$ $=1.77 \mathrm{~A}$. Here $I_{m}=\frac{4}{a^{2}} \Delta I_{C m \max }=4.19 \mathrm{~A}$.
To reconcile the scale of the quantities in the direct channel of deviation, coefficients are introduces (Fig. 2): $k=\frac{a}{4 \Delta I_{C m \max }}$ (without taking into account transmission coefficients of sensors and $u_{T R m}=1$ ) and $j=U / u_{T R m}$.

Without taking into account the modulation components, the «smooth» component of the reactor voltage according to (1)

$$
u_{L}^{1}=u_{C}^{1}-u_{1}=L \frac{d i^{1} C}{d t}=j u_{K}-u_{1} \quad\left(u_{K} \quad\right. \text { is the }
$$

control voltage varying within $\left(-u_{T R m}, u_{T R m}\right), u_{C}^{1}, i_{C}^{1}$ are the voltage and current without taking into account modulation components). From here $u_{K}=\frac{L}{j} \frac{d i^{1} C}{d t}+\frac{u_{1}}{j}$. Error $\Delta i_{C A V}=0$ provided that $i_{C}^{*}=i_{C}^{1}$, respectively, $\frac{d i^{*} C}{d t}=\frac{d i^{1} C}{d t}$. From here

$$
u_{K}=\frac{L}{J} \frac{d{ }^{*}{ }_{C}}{d t}+\frac{u_{1}}{j} .
$$

In the case $i_{C}{ }_{C}=0$, the value $u_{K}=u_{1} / j$. The voltage $u_{1}$ is measurable and the static error can be compensated by the introduction of the corresponding connection (link $K$ in Fig. 2).

The exclusion of the current error caused by the perturbation by the control signal is possible using the differential link of dynamic compensation (DC) according to (9) in the AVI current assignment channel.

In real conditions, $U_{1}$ varies in certain limits. With the change of $U_{1}$ at constant $f_{M}$ (8) $b^{\prime}=b / U_{1} *$ ( $U_{1}^{*}=U_{1} / U_{1 N}$, where $U_{1 N}$ is the nominal voltage), $a^{\prime}=a / U_{1}^{*}, c^{\prime}=\frac{a^{\prime} b c}{b^{\prime} a}$, which requires readjustment of the CCC. Another version of the compensation of static error is the introduction of the integrative link (Fig. 4) with the coefficient $g=f_{M} / k$, which calculates the actual value of $\Delta i_{C A V}(t)$ and adds it to the signal of deviation of current.

The proposed structure of the CCC of the AVI (Fig. 4) contains final devices, a proportional link with coefficient $k$, an integrative link, multipliers, a block of comparators BC, a generator of reference voltage GRV, a block of phase auto-adjustment of frequency PLL, a link of dynamic compensation DC. According to the signal of the setting of the amplitude of the current of the grid $I^{*}{ }_{1 m}$ from the output of the external voltage regulator OR (it supports the voltage at the AVI input at a given level $\left.U=U^{*}\right)$ a sinusoidal signal of the grid current setting $i^{*}{ }_{1}$ is formed, which, when generating energy of the SC to the grid is shifted relative to voltage $u_{1}$ by $180^{\circ}$, and in the case of power consumption from the grid coincides by the phase. The AVI current setting is determined taking into account $i_{L}$ and the capacitive current component of the filter with the amplitude $I_{f m(1)}=\omega C_{f} U_{1 m}$. PLL according to the DG voltage $u_{1}=U_{1 m} \sin \omega t$ and the given value of the angular frequency $\omega_{0}$ forms signals $\sin \omega t, \cos \omega t$. 


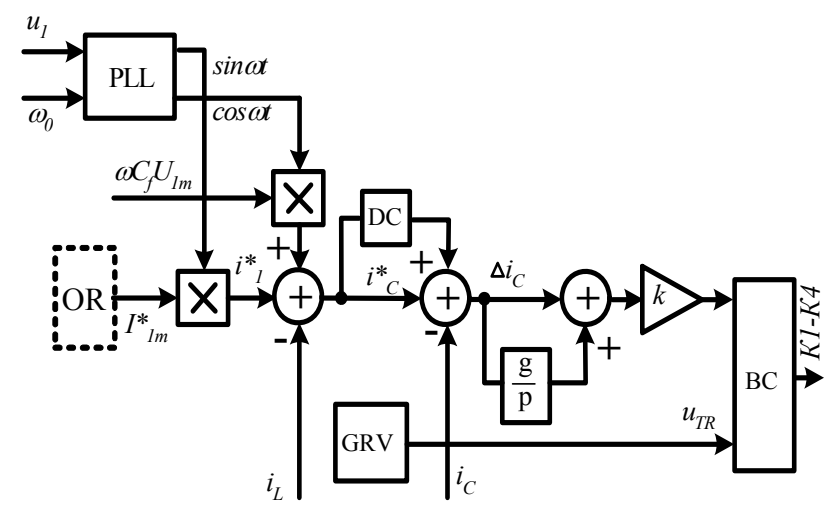

Fig. 4. CCC structure

Simulation in Matlab and its results. It made with combination of nonlinear load (uncontrolled rectifiers with output capacitance filter and $R L$-load) and $R L$-load $\left(I_{L m(1)}=19.6 \mathrm{~A}, \varphi_{(1)}=27^{\circ}\right)$. The DG contains the resistances $R=0.02 \Omega, X_{L}=0.02 \Omega$. Reactor with $L=0.0042 \mathrm{H}$ and $\mathrm{R}=0.1 \Omega, R_{f}=0.3 \Omega, C_{f}=60 \mu \mathrm{F}$. AVI parameters: $I_{C \max }=25 \mathrm{~A}, f_{M}=6800 \mathrm{~Hz}, U=405 \mathrm{~V}$ $(a=1.3)$.

Three variants of CCC are considered: variant $1-$ with DC and compensatory connection by $u_{1}$; variant $2-$ with DC and the integrating link; variant 3 - using PIregulator with adjustment on the symmetric optimum

$$
W(p)=\frac{4 L}{8 K T_{\mu}}+\frac{L}{8 K T_{\mu}^{2} p}\left(T_{\mu}=1 / f_{M}, K=k \cdot j\right) .
$$

Variant 3 at nonlinear load is operational only with DC and compensating link by $u_{1}$ and has the worst performance at small DG current values.

For example, in the case of $I^{*}{ }_{1 m}=3 \mathrm{~A}$, the value $I_{1 m(1)}=2.973 \mathrm{~A}, \mathrm{THD} i_{1}=4.79 \%$. Under the same conditions for variant $1 I_{1 m(1)}=2.943 \mathrm{~A}$, THD $i_{1}=3.41 \%$, for variant $2 I_{1 m(1)}=2.966 \mathrm{~A}, \mathrm{THD} i_{1}=2.68 \%$. In addition, variant 2 has the best DG current spectrum (Fig. 5) and provides THD $i_{1} \leq 5 \%$ in the range of values of $I_{1 m}$ up to $0.05 I_{1 m \text { max }}\left(I_{1 m \text { max }}\right.$ in this case is $\left.35.35 \mathrm{~A}\right)$. In the case of change of $u_{1}$, variant 2 does not need to be readjusted, so by $U^{*}{ }_{1}=0.85$ at $I^{*}{ }_{1 m}=3 \mathrm{~A}, I_{1 m(1)}=2.97 \mathrm{~A}$, THD $i_{1}=2.5 \%$. In variant 1 , under the same conditions, $I_{1 m(1)}=3.3 \mathrm{~A}, \mathrm{THD} i_{1}=2.83 \%$, which implies a change in the coefficient in the link $K$ (Fig. 2).

Oscillograms of $u_{1}, u_{C}, i_{1}, \Delta I_{C m}(t)$ at the linear load with the DC are shown in Fig. 6. Oscillograms of $u_{1}, u_{C}$, $i_{1}, i_{C}, i_{L}$ for $I^{*}{ }_{1 m}=3 \mathrm{~A}$ at the combined linear and nonlinear load (rectifiers with capacitive filter and $R L$ load) for variant 2 are shown in Fig. $7\left(I^{*}{ }_{1 m}=3 \mathrm{~A}\right.$, $\left.I_{1 m(1)}=2.97 \mathrm{~A}, \mathrm{THD} i_{1}=2.97 \%\right)$.

For comparison in [3] with use in the CCC of the PIregulator at $f_{M}=20 \mathrm{kHz}, I_{1 m}=10 \mathrm{~A}\left(I_{C m}=20 \mathrm{~A}\right.$, current amplitude of the nonlinear load $I_{L m}=9 \mathrm{~A}$ ), the value of $\mathrm{THD} i_{1}=4.8 \%$.

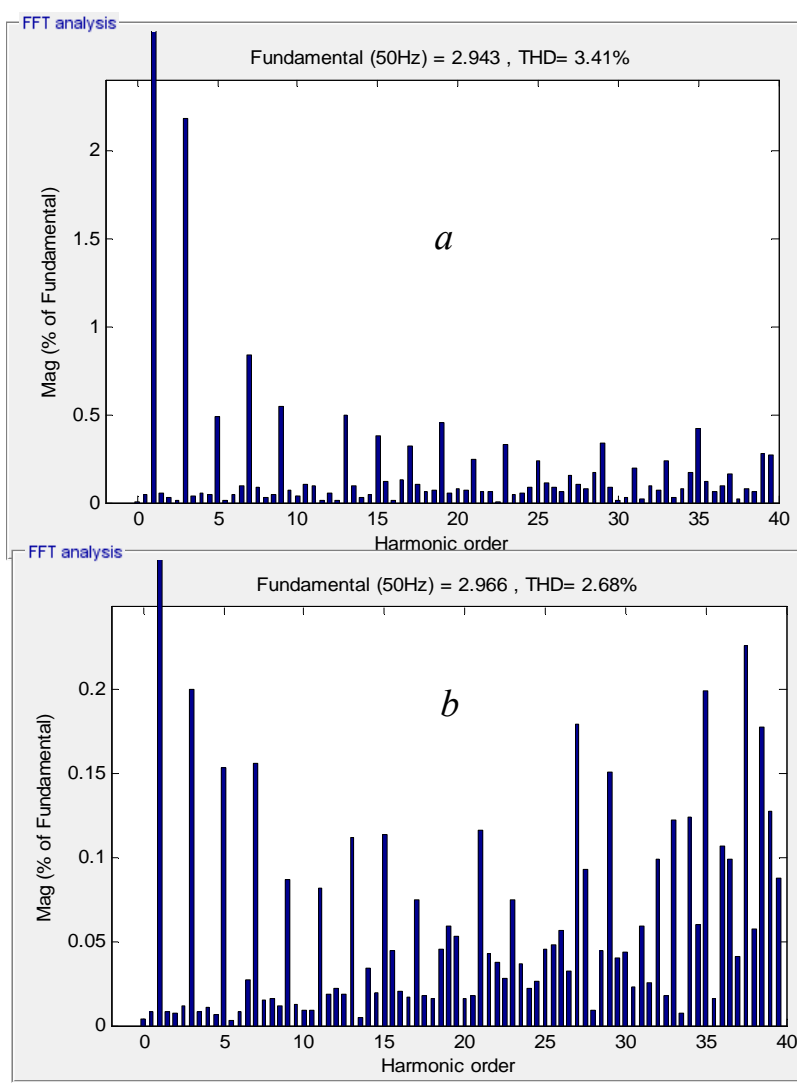

Fig. 5. DG current spectra: $a$ - variant $1 ; b$ - variant 2

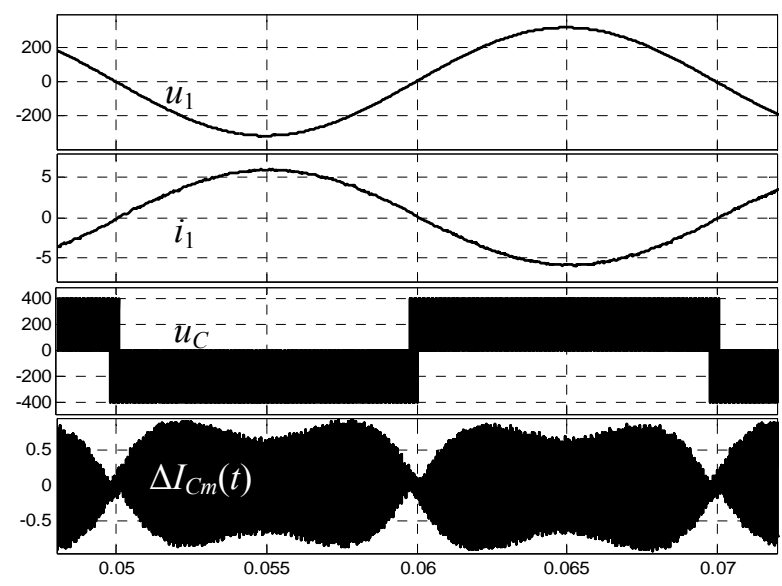

Fig. 6. Oscillograms of voltage and currents at linear load

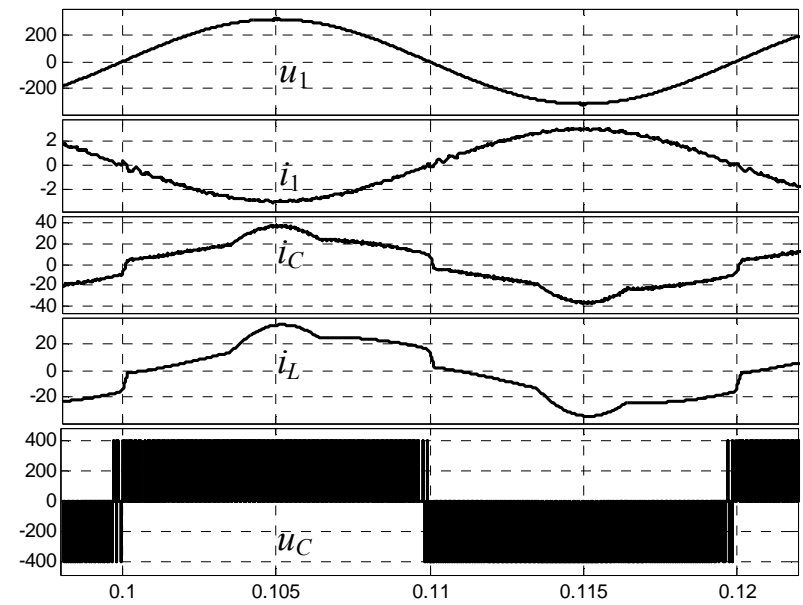

Fig. 7. Oscillograms of voltage and currents at combined load 


\section{Conclusions.}

Based on the received dependencies of the amplitude of the pulsations of the AVI output current and the fundamental harmonic error according to the voltage at the AVI input, the PWM frequency and the inductance of the output reactor, the parameters of the links to compensate for disturbing influences are justified. It is shown that the compensation of the perturbation of the DG voltage using in the channel of the current deviation of the integral link does not require readjustment in the event of a change in the voltage of the grid. The proposed structure of the CCC of the multifunctional AVI with a combination of proportional, integrative and differential links with their respective parameters allows for a limited value of PWM frequency of $6800 \mathrm{~Hz}$ to expand the range of current values $i_{1}$ at the point of connection to the grid in the direction of lower values up to 0.05 from the maximum current value at the value of $\mathrm{THD} i_{1} \leq 5 \%$ In this case, the value of the inverter voltage and the PWM frequency are determined according to the DG voltage, the reactor inductance, the maximum values of the AVI current and the amplitude of its pulsations. The results are obtained for relative values: amplitude of current pulsations $c=0.0025$, the voltage drop on the reactor at the maximum current (for the 1st harmonic) $b=0.15$ and $a=1.3$. A further direction of work is the development of a model for researching the AVI operation, taking into account the discreteness of the operation of the digital control system, to clarify the requirements for its elements and to assess real indicators.

\section{REFERENCES}

1. Zeng Z., Yang H., Zhao R., Cheng C. Topologies and control strategies of multi-functional grid-connected inverters for power quality enhancement: A comprehensive review. Renewable and Sustainable Energy Reviews, 2013, vol.24, pp. 223-270. doi: 10.1016/j.rser.2013.03.033.

2. Vaquero J., Vázquez N., Soriano I., Vázquez J. GridConnected Photovoltaic System with Active Power Filtering Functionality. International Journal of Photoenergy, vol. 2018, pp. 1-9. doi: 10.1155/2018/2140797.

3. Da Silva S.A.O., Sampaio L.P., Campanhol L.B.G. Singlephase grid-tied photovoltaic system with boost converter and active filtering. 2014 IEEE 23rd International Symposium on Industrial Electronics (ISIE), Jun. 2014. doi: 10.1109/isie.2014.6865013.

4. Denizar C. Martins, Kleber C. A. de Souza. A single-phase grid-connected PV system with active power filter. International journal of circuits, systems and signal processing, 2008, iss.1, vol.2, pp. 50-55.

5. Vigneysh T., Kumarappan N. Grid interconnection of renewable energy sources using multifunctional grid-interactive converters: A fuzzy logic based approach. Electric Power Systems Research, 2017, vol.151, pp. 359-368. doi: 10.1016/j.epsr.2017.06.010.

6. Shavelkin A., Shvedchykova I. Multifunctional converter for single-phase combined power supply systems for local objects with a photovoltaic solar battery. Technical electrodynamics, 2018, no.5, pp. 92-95. doi: 10.15407/techned2018.05.092.

7. Wu T.-F., Nien H.-S., Shen C.-L., Chen T.-M. A SinglePhase Inverter System for PV Power Injection and Active Power Filtering With Nonlinear Inductor Consideration. IEEE Transactions on Industry Applications, 2005, vol.41, no. 4, pp. 1075-1083. doi: 10.1109/tia.2005.851035.

8. Mendez I., Vazquez N., Vaquero J., Vazquez J., Hernandez C., Lopez H. Multifunctional grid-connected photovoltaicsystem controlled by sliding mode. IECON 2015 - 41st Annual Conference of the IEEE Industrial Electronics Society, Nov. 2015. doi: 10.1109/iecon.2015.7392286.

9. Shavelkin A.A. Structures of single-phase converters units for combined electrical supply systems with photoelectric solar panels. Technical electrodynamics, 2018, no.2, pp. 39-46. (Rus). doi: 10.15407/techned2018.02.039.

10. 1547-2018 - IEEE Standard for Interconnection and Interoperability of Distributed Energy Resources with Associated Electric Power Systems Interfaces. Date of Publ. 6 April 2018. doi: 10.1109/IEEESTD.2018.8332112.

\section{Received 07.02.2019}

O.O Shavelkin ${ }^{1}$, Doctor of Technical Science, Professor,

V.V. Kaplun ${ }^{1}$, Doctor of Technical Science, Professor,

I.O. Shvedchykova ${ }^{1}$, Doctor of Technical Science, Professor,

${ }^{1}$ Kyiv National University of Technologies and Design,

2, Nemirovich-Danchenko Str., Kyiv, 01011, Ukraine, phone +380 509720629 ,

e-mail: shavolkin@gmail.com, ishved89@gmail.com

How to cite this article:

Shavelkin O.O, Kaplun V.V., Shvedchykova I.O. Error elimination for current control loop for multi-functional singlephase grid-connected inverter. Electrical engineering \& electromechanics, 2019, no.4, pp. 35-40. doi: 10.20998/2074272X.2019.4.05. 